\title{
Małgorzata Moszyńska
}

Państwowa Wyższa Szkoła Zawodowa w Elblągu

\section{Beata Antoszewska}

Uniwersytet Warmińsko-Mazurski w Olsztynie

\section{Praca nauczyciela szkoły przyszpitalnej w perspektywie procesu inkluzji ucznia ze specjalnymi potrzebami edukacyjnymi - z doświadczeń nauczycieli szkół przyszpitalnych w województwie warmińsko-mazurskim}

\begin{abstract}
Artykuł w pierwszej części zawiera teoretyczne wprowadzenie do zagadnienia inkluzji i pracy nauczycieli w szkołach przyszpitalnych. Druga część prezentuje wyniki badań otrzymane w efekcie badań jakościowych osadzonych w paradygmacie interpretatywnym. Wybór wskazanego paradygmatu powiązany był z potrzebą uzyskania "głębszego" rozumienia zjawiska inkluzji. Cel badań dotyczył poznania i opisania pracy nauczycieli szkół przyszpitalnych przez pryzmat inkluzji ucznia ze specjalnymi potrzebami edukacyjnymi. Uzyskane dane i jakościowa ich analiza pozwoliły wyłonić szesśc wspólnych obszarów procesu inkluzji: perspektywiczny, ciągłości, niepewności, teraźniejszości, teoretyzacji zadań i uprzedmiotowienia. Każdy z nich opisuje działania podejmowane przez nauczycieli szkól przyszpitalnych wobec ucznia przebywającego w szkole przyszpitalnej. Badania wskazują, iż nauczyciele koncentrują się przede wszystkim na realizacji zadań związanych z edukacyjna funkcją szkoły.
\end{abstract}

Słowa kluczowe: uczeń, szkoła przyszpitalna, inkluzja

\section{The work of a hospital school teacher in a view of the process of inclusion of a student with special educational needs- obtained from the experience of the hospital school teachers in Warmian-Masurian Voivodeship}

The paper starts with a theoretical introduction into the issue of inclusion and work of teachers in hospital schools. Its second part presents research results collected in the qualitative study set in the interpretative paradigm. The choice of the paradigm is related to the need to gain a "deeper" insight into the phenomenon of inclusion. The aim of the study was to get to know and describe work of teachers of hospital schools from the perspective of inclusion of a student with special educational needs. The obtained data and its qualitative analysis led to specifying six common 
areas of the inclusion process: the perspective, consistency, insecurity, presence, sentence theorizing and objectification. Each of them describes actions taken by the teachers, who work in the hospital school, towards pupils, who study at the same school. The investigations show, that teachers concentrate mostly on the completion of tasks, that are associated with the educational function of the school.

Keywords: student, hospital school, inclusion

\section{Wprowadzenie}

W definicjach pojęcia „inkluzja” wskazuje się, iż jest ona kształceniem uczniów z niepełnosprawnością, nieuwzględniającym podziałów, a zapewniającym jedność w odniesieniu do różnorodnych potrzeb uczniów oraz realizacją edukacji w najbliższym środowisku. Inkluzja jest procesem stwarzającym możliwości oraz szanse niezbędne do uczestnictwa w życiu w zakresie ekonomicznym, społecznym oraz kulturalnym [Szatur-Jaworska 2005: 64]. Proces inkluzji w Polsce popularyzowany jest przez wielu autorów wśród których można wymienić m.in. Iwonę Chrzanowską, Amadeusza Krause, Grzegorza Szumskiego czy Zenona Gajdzicę. Sławomira Sadowska [2016: 125-144] podkreśla, iż polityka państwa w sferze edukacji określana jest dziś przez argumenty na rzecz sprawiedliwości społecznej i równości. Inkluzja w rozumieniu autorki jest kluczem do budowania nowego modelu edukacji poprzez wartości - równość i sprawiedliwość. Określenie warunków powodzenia inkluzji wymaga wielu dyskusji i ustaleń. Ratyfikowanie przez Polskę konwencji ONZ o prawach osób niepełnosprawnych powinno usprawnić proces edukacji inkluzyjnej dający uczniom ze specjalnymi potrzebami edukacyjnymi możliwości kształtowania swojej podmiotowości w ogólnodostępnym systemie edukacji. Zenon Gajdzica [2013: 5] zgłasza konieczność zmian nie tylko prawodawczych, ale przede wszystkim zmian jakościowych w systemie oświaty polskiej oraz świadomości nauczycieli.

Inkluzja jako nowa idea edukacyjna dotyczy wszystkich szkół. Szkoła przyszpitalna + to bez wątpienia ważna przestrzeń, w której należy mówić o inkluzji, ponieważ realizuje ona funkcje tożsame z funkcjami każdej innej szkoły. Nauczyciele szkół przyszpitalnych odgrywają istotną rolę w całościowym procesie wdrażania ucznia w role społeczne, które na czas choroby zostały nieco zmienione (np. realizuje on rolę ucznia w nieco innych warunkach niż jego zdrowi rówieśnicy).

Warto jednak zauważyć, iż szkoła przyszpitalna nie jest łatwo dostępna do naukowego zgłębiania. Wynika to $\mathrm{m}$. in. ze specyfiki jej funkcjonowania - brak sal lekcyjnych; niewielka liczba nauczycieli; brak stałej liczby uczniów, a wręcz przeciwnie, duża ich rotacja. Uczniem szkoły przyszpitalnej jest każde dziecko, które podlega obowiązkowi szkolnemu, które ze względu na stan zdrowia znajduje się w szpitalu/klinice czy sanatorium lub innej placówce leczniczej. Realizuje ono 
programy nauczania zgodnie z podstawami kształcenia ogólnego szkół, w których dotychczas pobierało naukę [por. Gołubiew-Konieczna 2011: 40-54] Nauczyciele są nie tylko dydaktykami, ale często terapeutami dla chorych dzieci. Pomiędzy nimi a uczniami nawiązuje się często silna więź emocjonalna, pozytywnie oddziałująca na efekt procesu leczenia. Zajęcia dydaktyczne zapewniają dzieciom poczucie normalności i bezpieczeństwa, pozytywnie wpływając na samoakceptację dziecka.

Dziecko w szkole przyszpitalnej ma możliwość:

1. Kontynuowania procesu kształcenia i realizacji obowiązku szkolnego i obowiązku nauki.

2. Nabywania umiejętności radzenia sobie w sytuacjach trudnych wynikających z choroby - osiągania sukcesu.

3. Zdobywania doświadczeń $\mathrm{w}$ zakresie adekwatnego postrzegania własnych możliwości ograniczonych chorobą oraz kształtowania prawidłowych interakcji społecznych.

4. Zaspokajania potrzeb emocjonalnych i rozwojowych, wspomagających proces leczenia [Chęcińska 2005: 91-92].

Nauczyciele pracują w szkołach przyszpitalnych według planu lekcji, który jak wskazują dyrektorzy, ustalany jest na bieżąco zgodnie z zapotrzebowaniem i liczbą uczniów przebywających na oddziałach/w klinikach. Zazwyczaj uczniowie nauczani są wszystkich przedmiotów, w tym również dwóch języków obcych. Zajęcia dydaktyczne obywają się w zespołach klasowych lub indywidualnie przy łóżku chorego dziecka (zależy to od możliwości lokalowych szkoły i funkcjonowania szpitala/kliniki), przy wykorzystaniu kart pracy dostosowanych do indywidualnych potrzeb i możliwości uczniów. Indywidualizacja pracy pozwala na wyrównywanie ewentualnych zaległości i opanowywania nowych treści, które przepracowują zdrowi rówieśnicy w szkole macierzystej. Uczeń uzyskuje stopnie, które po zakończeniu leczenia są przekazywane szkole macierzystej i honorowane przez pracujących $\mathrm{w}$ niej nauczycieli. Ocenianie dziecka przewlekle chorego, spełniając funkcję informacyjną czy wychowawczą, jak i psychologiczną oraz terapeutyczną, posiada kluczowe znaczenie dla wzmocnienia potencjałów energetycznych $w$ walce o zdrowie. Ocenianie wymaga od nauczycieli wielowymiarowego spojrzenia na ucznia przewlekle chorego, uwzględniającego wysiłek wkładany w uzupełnienie lub opanowanie materiału nauczania (wynikającego z programu), jak i mobilizację do dalszej pracy. Ocena uzyskiwana przez ucznia przewlekle chorego powinna być obiektywna - sprawiedliwie ustalona i najbardziej adekwatna na dany moment - wyrażająca zarówno poziom wiedzy, jak i wkład włożony w wykonaną pracę. Jej walor wychowawczy wzmacnia dobre samopoczucie dziecka oraz chęć do nauki [Bakoń, Siedlecka 2005: 101-105]. Dzięki funkcjonowaniu szkół przyszpitalnych, każde chore dziecko, pomimo 
obciążeń wynikających z przebiegu procesu chorobowego, hospitalizacji i leczenia, nie musi rezygnować z nauki, a tym samym ma możliwość uzyskania klasyfikacji semestralnych.

Tabela 1. Liczba uczniów pobierających naukę $\mathrm{w}$ szkołach przyszpitalnych w województwie warmińsko-mazurskim ${ }^{1}$

\begin{tabular}{|c|c|c|c|c|c|c|c|c|}
\hline \multirow{3}{*}{$\begin{array}{c}\text { Nazwa } \\
\text { organizacji }\end{array}$} & \multirow{3}{*}{ Nazwa } & \multirow{3}{*}{ Тур } & \multicolumn{6}{|c|}{$\begin{array}{l}\text { Liczba uczniów/wychowanków oddziałów specjal- } \\
\text { nych zorganizowanych w podmiotach leczniczych } \\
\text { i w jednostkach pomocy społecznej - suma }\end{array}$} \\
\hline & & & \multicolumn{6}{|c|}{ Data spisu } \\
\hline & & & $\begin{array}{c}30.09 \\
2015\end{array}$ & $\begin{array}{c}31.03 . \\
2016\end{array}$ & $\begin{array}{c}30.09 . \\
2016\end{array}$ & $\begin{array}{c}31.03 . \\
2017\end{array}$ & $\begin{array}{c}30.09 . \\
2017\end{array}$ & $\begin{array}{c}31.03 . \\
2018\end{array}$ \\
\hline \multirow{2}{*}{$\begin{array}{l}\text { Zespół Szkół } \\
\text { Specjalnych } \\
\text { w Olsztynie }\end{array}$} & $\begin{array}{l}\text { Szkoła Podstawo- } \\
\text { wa Nr } 21 \text { Specjal- } \\
\text { na w Olsztynie }\end{array}$ & $\begin{array}{l}\text { szkoła } \\
\text { podsta- } \\
\text { wowa }\end{array}$ & 13 & 11 & 11 & 11 & 12 & 14 \\
\hline & $\begin{array}{l}\text { Gimnazjum Nr } 19 \\
\text { Specjalne } \\
\text { w Olsztynie }\end{array}$ & $\begin{array}{l}\text { gimna- } \\
\text { zjum }\end{array}$ & 19 & 18 & 19 & 16 & 15 & 15 \\
\hline $\begin{array}{l}\text { Zespół } \\
\text { Placówek } \\
\text { Specjalnych }\end{array}$ & $\begin{array}{l}\text { Gimnazjum nr } 20 \\
\text { Specjalne dla Ucz- } \\
\text { niów z Chorobami } \\
\text { Przewlekłymi }\end{array}$ & $\begin{array}{l}\text { Gimna- } \\
\text { zjum }\end{array}$ & 36 & 35 & 34 & 33 & 31 & 21 \\
\hline $\begin{array}{l}\text { Zespół } \\
\text { Placówek } \\
\text { Specjalnych }\end{array}$ & $\begin{array}{l}\text { Przedszkole Miej- } \\
\text { skie nr } 22 \text { Specjal- } \\
\text { ne dla Dzieci } \\
\text { z Chorobami } \\
\text { Przewlekłymi }\end{array}$ & $\begin{array}{l}\text { przed- } \\
\text { szkole }\end{array}$ & 50 & 45 & 45 & 49 & 48 & 46 \\
\hline $\begin{array}{l}\text { Zespół } \\
\text { Placówek } \\
\text { Specjalnych }\end{array}$ & $\begin{array}{l}\text { Szkoła Podstawo- } \\
\text { wa nr } 20 \text { Specjalna } \\
\text { dla Uczniów } \\
\text { z Chorobami } \\
\text { Przewlekłymi }\end{array}$ & $\begin{array}{l}\text { szkoła } \\
\text { podsta- } \\
\text { wowa }\end{array}$ & 54 & 49 & 50 & 50 & 49 & 57 \\
\hline
\end{tabular}

Źródło: System Informacji Oświatowej, przygotował: Leszek Piskorski, Wydział Edukacji Urzędu Miasta Olsztyna.

Na terenie województwa warmińsko-mazurskiego istnieją obecnie trzy szkoły przyszpitalne: Zespół Placówek Specjalistycznych przy Wojewódzkim Specjalistycznym Szpitalu Dziecięcym, Zespół Szkół Specjalnych przy Wojewódzkim Zespole Lecznictwa Psychiatrycznego w Olsztynie oraz Zespół Szkół Podstawowo-Gimnazjalnych przy Wojewódzkim Szpitalu Rehabilitacyjnym dla Dzieci

1 Średnia miesięczna liczba uczniów w szkołach w przedszkolach w podmiotach leczniczych i jednostkach pomocy społecznej według zasady: suma średnich stanów miesięcznych w dniach nauki szkolnej od września 2017 r. do marca 2018 r., podzielona przez 7. Średnie stany miesięczne ustalamy sumując stany dzienne $\mathrm{w}$ dniach nauki szkolnej $\mathrm{w}$ danym miesiącu, a następnie dzielimy przez liczbę dni nauki szkolnej w tym miesiącu. 
w Ameryce. Dane z województwa warmińsko-mazurskiego z lat 2015-2018 (por. tab. 1) wskazują na utrzymującą się liczbę uczniów w szkołach przyszpitalnych. Można domniemywać, iż corocznie nowa grupa dzieci chorych/uczniów będzie potrzebowała wsparcia od pracujących tam nauczycieli.

Zarówno wcześniejsze doświadczenia badawcze autorek związane ze środowiskiem nauczycieli (szkół ogólnodostępnych i przyszpitalnych), jak i zapoczątkowane w tym środowisku badania związane $\mathrm{z}$ inkluzją, stanowiły zachętę do rozszerzenia projektu badawczego $\mathrm{w}$ tym obszarze. $\mathrm{W}$ aktualnym projekcie badawczym objęto wszystkie trzy placówki² ${ }^{2}$ oraz zastosowano jakościowe podejście badawcze.

\section{Metodologiczne podstawy badań}

Celem badań była próba opisania doświadczeń nauczycieli oraz znaczeń, jakie nadają oni swojej pracy w szkołach przyszpitalnych w pryzmacie inkluzji ucznia ze specjalnymi potrzebami edukacyjnymi.

Główne pytanie badawcze sformułowano następująco: w jaki sposób nauczyciele pracujący w szkołach przyszpitalnych realizują proces inkluzji ucznia ze specjalnymi potrzebami edukacyjnymi? Techniką zbierania danych był wywiad kwestionariuszowy przeprowadzony indywidualnie z nauczycielami (zarówno nauczycielami poszczególnych przedmiotów, jak i wychowawcami czy terapeutami) pracującymi w szkołach przyszpitalnych.

Kwestionariusz składał się z siedmiu pytań otwartych. Starano się stworzyć odpowiednią atmosferę, w której nauczyciele mieliby poczucie, iż są pytani o własne doświadczenia, o wiedzę, której badacz nie posiada, a nie sądy czy własne opinie. Nauczyciele kontrolowali to, o czym chcą mówić i jak głęboko odnosić się do stawianych pytań.

Poszukując drogi do kompleksowego, wiernego i autentycznego przedstawienia perspektywy badanych, podjęto decyzję o dokonaniu analizy zebranego materiału w paradygmacie jakościowym, poprzez jakościową analizę treści. Kluczowym procesem $\mathrm{w}$ analizowaniu zebranych treści było kodowanie. Earl Babbie definiuje je jako „klasyfikowanie lub kategoryzowanie pojedynczych fragmentów danych połączone z (...) systemem ich odszukiwania" [Babbie 2003: 406]. Procedura ta pomogła zespołowi badawczemu w odszukaniu interesujących w kontekście prowadzonych badań fragmentów. Kodowanie miało także pomóc w odkryciu

2 Prezentowany artykuł jest rozszerzoną wersją tekstu autorek: B. Antoszewska, M. Moszyńska, Uczeń ze specjalnymi potrzebami edukacyjnymi a inkluzja. Wymiar teoretyczny i praktyczny pracy nauczycieli w szkole przyszpitalnej, który został oddany do druku w „Kwartalniku Pedagogicznym” w $2018 \mathrm{r}$. 
prawidłowości, które z kolei wskażą teoretyczne wyjaśnienie badanego procesu inkluzji w szkołach przyszpitalnych. Analizując zebrany materiał, szukano klucza kategoryzacyjnego, który pomógłby tworzyć zbiór kategorii, pojęć, o których traktują zebrane i poddane analizie treści. Konstruowanie klucza polegało na wielokrotnej i uważnej lekturze całości zebranych tekstów, ze szczególnym uwrażliwieniem na powtarzalność, wzajemność powiązań pewnych obszarów tematycznych, ale i zamiarze uchwycenia różnorodności opisywanych zagadnień. Prowadzone badania ulokować więc można w paradygmacie interpretatywnym. Paradygmat ten stanowi model postępowania badawczego, gdzie przedmiotem zainteresowania naukowego jest zrozumienie subiektywnego doświadczenia ludzkiego. Środkiem do tego celu jest testowanie wiedzy praktycznej konkretnych grup społecznych [Rubacha 2003: 61-62].

Badania prowadzono w okresie od lutego do czerwca 2018 roku. Do grupy badawczej zakwalifikowani zostali wszyscy nauczyciele zatrudnieni w szkołach przyszpitalnych w Olsztynie, nawet ci, którzy są zatrudnieni w niepełnym wymiarze godzin, a zatem szkoła przyszpitalna nie jest ich jedynym miejscem pracy. Badaniami objęto 37 nauczycieli, w tym 8 mężczyzn i 29 kobiet, w wieku od 30 do 64 lat. Wśród badanych nauczycieli było 29 nauczycieli dyplomowanych, 6 mianowanych i 2 kontraktowych. Charakteryzując grupę pod kątem zatrudnienia można ją podzielić na 26 nauczycieli pełnoetatowych i 11 nauczycieli zatrudnionych w niepełnym wymiarze godzin. Staż pracy badanych to przedział: 10-40 lat.

\section{Wyniki badań}

Zebrane informacje wynikające z doświadczeń nauczycieli pozwoliły wyłonić pewne wspólne obszary procesu inkluzji (por. ryc. 1).

\begin{tabular}{ll}
\hline & \multicolumn{1}{c}{ perspektywiczny } \\
\cline { 2 - 2 } obszary inkluzji & ciagłości \\
\cline { 2 - 2 } & niepewności \\
\cline { 2 - 2 } teraźniejszości \\
${ } }$ \\
\hline uprzedmiotowienia
\end{tabular}

Rycina 1. Obszary działań badanych nauczycieli szkół przyszpitalnych w kontekście inkluzji Źródło: Opracowanie własne 
Większość badanych nauczycieli, pracując z uczniem w szkole przyszpitalnej, nawiązywała kontakt $\mathrm{z}$ wychowawcą ze szkoły macierzystej i pozostawała z nim $\mathrm{w}$ kontakcie. Byli to nauczyciele - wychowawcy i nauczyciele pełnoetatowi. Myśląc o uczniu badani własną pracę postrzegali perspektywicznie. Żaden nauczyciel z tej grupy nie koncentrował się na zadaniu tu i teraz. Nauczyciele jednak nie wspominali o tym, że interesują się sytuacją ucznia po jego powrocie do domu i szkoły. Warto zaznaczyć, iż badani nauczyciele utrzymujący kontakt ze szkołą macierzystą, uzasadniali tę sytuację przede wszystkim możliwością pozyskania szerszej wiedzy o uczniu, jego możliwościach i trudnościach. Doceniali jednocześnie rolę nauczycieli ze szkoły macierzystej, a siebie postrzegali jako czynnych uczestników obopólnych działań na rzecz powrotu ucznia do macierzystego środowiska (szkolnego):

Nauczyciel ze szkoły macierzystej ucznia posiada cenne informacje o funkcjonowaniu naszego ucznia-pacjenta. Możemy wspólnie wypracować mu drogę, która pomoże mu bezpośrednio wrócić do swojego środowiska (18/K).

[...] kontaktuję się z dyrektorami, pedagogami i psychologami szkolnymi, wychowawcami w celu przygotowania ich na powrót ucznia po leczeniu szpitalnym, zwłaszcza w sytuacjach ryzykownych, gdy proces terapii wymaga systematycznej kontynuacji i wsparcia w terenie, w którym to jest $z$ różnych przyczyn trudne, a bywa że niemożliwe do zrealizowania, bądź nierozwiązany problem np. rodzinny czy osobisty relacyjny, co może rzutować na postawy, zachowania i ryzykowne wybory ucznia mogace spowodować pogorszenie stanu [...] (19/M).

W przypadku uczniów szkół przyszpitalnych elementem najważniejszym w zakresie inkluzji jest współpraca szkoły przyszpitalnej ze szkołą macierzystą, nie tylko na poziomie kadr pedagogicznych, ale przede wszystkim grupy rówieśniczej. Dziecko pomimo hospitalizacji chce być w stałym kontakcie z gronem rówieśników. To zapewne jedno z ważnych pragnień. Z kolei zaległości związane z przerabianym materiałem, pomimo iż są istotne, stanowią dla niego dalszą perspektywę. Istotne są działania nauczycieli podejmowane $\mathrm{w}$ wymiarze formalnym, jednak ważne, a nawet istotniejsze są działania zawierające się w opiekuńczej i wychowawczej funkcji szkoły. Połączenie wymiaru formalnego z innymi wymiarami pracy skutkuje wzmocnieniem sukcesu nauczycieli ze szkół przyszpitalnych, przyczyniając się nie tylko do ponownego płynnego włączenia do zajęć w szkole macierzystej, czyli inkluzji, ale także (a nawet równocześnie) zapewnienia lepszych warunków leczenia. Holistyczny, interdyscyplinarny model opieki jest niezbędny w procesie pełnego powrotu do zdrowia ucznia, który podczas hospitalizacji znajduje się w podwójnej roli: ucznia i jednocześnie pacjenta.

W uzyskanym materiale badawczym tylko nieliczni nauczyciele wspominali o formalnym wymiarze kontaktów z rówieśnikami - sprowadzając własne działania przede wszystkim do zachęcania, by uczniowie nawiązywali go: 
Staram się, aby uczniowie byli w kontakcie ze swoimi koleżankami, kolegami, aby być na bieżąco z tematami lekcji (36/K).

Odmienny sposób pracy prezentowali nauczyciele, którzy nie pozostawali w kontakcie z nauczycielami ze szkoły macierzystej. Tę grupę nauczycieli cechowało podejście skoncentrowane na teraźniejszości, bowiem w sposób bardzo transparentny ograniczała ona swoje zainteresowania, a tym samym i zadania, do aktualnej rzeczywistości ucznia - sytuacji i miejsca jego pobytu. Najistotniejsze było dla tych nauczycieli to, co dzieje się z uczniem na oddziale i podczas lekcji w szkole przyszpitalnej.

Kontaktuje się w wyjątkowych sytuacjach, kiedy potrzebuję dodatkowych informacji na temat sposobu pracy z dzieckiem, które wykazuje specyficzne potrzeby edukacyjne a nie zostata przekazana informacja (czasem tak się zdarza) (28/K).

W codziennej pracy nie mam potrzeby kontaktować się z nauczycielami ze szkoły macierzystej ucznia. Kontakty dotyczą zachowania ucznia i treści programowych (29/K).

Uczniowie przekazuja informacje od nauczycieli przedmiotów (33/K).

Badani z tej grupy swoje postępowanie najczęściej uzasadniali brakiem możliwości czy potrzeby, realizowaną funkcją (nauczyciel przedmiotu) lub formą zatrudnienia:

Jestem nauczycielem dochodzacym i o uczniu otrzymuję informację od wychowawcy ze szkoty przyszpitalnej (24/K).

Nie mam takiej potrzeby $(28 / \mathrm{K})$.

[...] Obowiązuje mnie ustawa o ochronie danych osobowych (25/K).

[...] Ponieważ prowadzę zajęcia pozalekcyjne (26/M).

[...] Nie, nie jestem wychowawca $(13 / \mathrm{K})$.

Praca nauczycieli skoncentrowana na przygotowaniu dziecka do powrotu do szkoły macierzystej ujawniła dbałość o ciągłość edukacji. Niemalże wszyscy nauczyciele wskazali, że cały pobyt dziecka w szpitalu jest przygotowaniem go do powrotu. Jest on jednak skoncentrowany przede wszystkim na zaakceptowaniu warunków szpitalnych, jak i wzmocnieniu wiary we własne możliwości. Oto przykładowe odpowiedzi:

Cały pobyt dziecka w szpitalu jest przygotowaniem go do powrotu do szkoty macierzystej (15K).

Początkowy etap pobytu dziecka poświęcam na zaklimatyzowanie się na oddziale szpitalnym (11K).

Początkowy etap pobytu dziecka poświęcam na pomoc w adaptacji do warunków szpitalnych. Praktycznie caty pobyt dziecka w szpitalu jest przygotowaniem go do powrotu do szkoty macierzystej (10K). 
Cały czas lekcje sa ukierunkowane na pomoc w powrocie dziecka do szkoty macierzystej (13K).

W trakcie pobytu dziecka w szpitalu wykorzystuję ten czas, aby uczeń nie miał dużych zaległości w nauce $(36 / \mathrm{K})$.

Staram się, aby uczeń nie miat zaległości, gdy wróci do swojej szkoły. Zachęcam dzieci do kontaktowania się z kolegami ze szkót [...] (30/K).

Tylko troje z badanych nauczycieli wyraziło odmienne stanowisko, wskazując, iż przygotowanie dziecka do powrotu do szkoły macierzystej nie stanowi celu ich pracy. Są to odpowiedzi badanych, którzy nie zbierali dodatkowych informacji o uczniach (byli to nauczyciele tworzący obszar teraźniejszości). Czytamy w odpowiedziach:

Nie jest to mój nadrzędny cel pracy (25/K).

Nie poświęcam, gdyż nie ma takiej potrzeby, aby nauczyciel wychowania fizycznego to robit. Mając $z$ dzieckiem 2 godziny w tygodniu (22/M).

Zwykle nie ma takiej potrzeby. Dzieci nie sq tak dlugo w naszej placówce (32/M).

Kolejną kwestią, która się pojawiła, jest sposób w jaki pracują badani nauczyciele. Wynika on przede wszystkim z zadań stojących przed nauczycielami szkoły przyszpitalnej. Nauczyciele wskazywali na indywidualizację pracy z uczniem o specjalnych potrzebach edukacyjnych, która umożliwia zarówno kontynuację nauki rozpoczętej w szkole ogólnodostępnej, jak i nadrabianie zaległości. Ten sposób pracy nazwany został teoretyzacją zadań. Odzwierciedla ona bardzo wyraźnie zadania i cele szkoły przyszpitalnej i stanowi formalną płaszczyznę obowiązków stawianych przed nauczycielem szkoły przyszpitalnej.

Pracując z uczniem, nauczyciele wykorzystują: karty pracy, dostępność określonych środków technicznych; dostosowanie do możliwości psychofizycznych i możliwości wysiłkowych; powszechne metody pracy, szczególnie metody aktywne; unikanie działań, które w sposób negatywny wpływają na ucznia; podejmowanie starań, by lekcja była dla ucznia miła, zakończyła się sukcesem; przyniosła konkretne korzyści, w postaci konkretnej wiedzy i umiejętności. Można wnioskować, że działania podejmowane przez nauczycieli szkół przyszpitalnych wpisują się szczególnie w dwa wymiary:

- dydaktyczny - nadrabianie zaległości, realizacja podstawy programowej, realizacja treści nauczania;

- wychowawczy - wzmacnianie wiary we własne możliwości, wzmacnianie poczucia własnej wartości.

Wszyscy badani nauczyciele twierdzą, że inkluzja jest procesem niezbędnym $i$ istotnym, natomiast nie są przekonani co do możliwości jej realizacji. Ten obszar, który w sposób mało precyzyjny nakreślał wizję przyszłości, określono obszarem niepewności. Pojawiają się stwierdzenia: 
[...] czy jest możliwa, nie wiem. Myślę, że nie można w tym przypadku generalizować. Każdy przypadek jest inny. Tak jak każde dziecko (24/K).

[...] w bardzo okrojony sposób (25/K).

Z kolei wskazywane czynniki pomagające projektować działania inkluzyjne dotyczyły przede wszystkim całościowej wiedzy o dziecku, współpracy z zespołem, chęci poznania dziecka przez nauczyciela. Badani duży nacisk kładli na działanie wieloosobowe.

Tylko nieliczni respondenci dostrzegali wymiar emocjonalny inkluzji (3 nauczycieli). Autorzy omawianych wypowiedzi inkluzję postrzegali jako proces dwutorowy - przygotowania dziecka do funkcjonowania w szpitalu i w szkole przyszpitalnej ( $w$ trakcie choroby) oraz przygotowania do powrotu do szkoły macierzystej (po chorobie).

Badani nauczyciele inkluzję widzą poprzez pryzmat techniczny i organizacyjny - co wskazuje na jej uprzedmiotowienie.

\section{Refleksje końcowe}

Przedstawione wyniki stanowią odpowiedź na pytanie, w jaki sposób nauczyciele pracujący $\mathrm{w}$ szkołach przyszpitalnych w województwie warmińsko-mazurskim realizują proces inkluzji ucznia ze specjalnymi potrzebami edukacyjnymi. Analiza materiału badawczego wyraźnie ukazała dysfunkcję systemu oświaty, której główna rola uparcie zawiera się i ogranicza do edukacyjnej roli szkoły. Pewnym wyjaśnieniem tego stanu rzeczy wydaje się być zaobserwowany przez Roberta Kwaśnicę odwieczny problem wspólistnienia w humanistyce dwóch racjonalności. Autor obrazuje ten problem, wskazując, że: „Ludzkie doświadczenie funkcjonuje na dwóch piętrach. Na pierwszym, w pełni i łatwo dostępnym świadomości człowieka, mieści się ta wiedza, do której się bezpośrednio odwołujemy opisując, wyjaśniając, wartościując rzeczywistość i określając normy działania. Jest to powierzchniowa struktura ludzkiego doświadczenia. Obejmuje ona to, co człowiek wie, że wie, czyli - to wszystko, co każdy z nas ma niejako pod ręką, podejmując interpretację zachodzących w jego otoczeniu zdarzeń. Na tym piętrze jesteśmy dobrze zadomowieni; żeby się tam znaleźć, nie trzeba specjalnie o to się starać. Wchodzimy tam bez wysiłku, naturalną koleją rzeczy, w ten sposób, że sięgamy po ustanowione już odpowiedzi i posługujemy się nimi bezwiednie, nie pytając o to, w jaki sposób zostały one ustanowione i dlaczego ich treść jest taka, a nie inna. Trudniej natomiast jest wejść na piętro wyższe, lepiej byłoby powiedzieć - głębsze. Trzeba to uczynić świadomie, podejmując w tym celu określony wysiłek, angażując do tego własną wolę. Jest to rzadziej przez nas odwiedzany 
obszar naszego doświadczenia; nie zawsze dostrzegamy powody, żeby się tam wybrać. Jest to głęboka struktura doświadczenia. W jej ramach mieszczą się kategorie, założenia i procedury interpretacyjne (...), na mocy których to, co wiemy o rzeczywistości, wydaje się nam oczywiste, pewne i nienaruszalne. Wybierając się na to piętro można się dowiedzieć, dlaczego ustalenia składające się na wiedzę podręczną tak właśnie, tzn. jako naturalne i wystarczające, nam się przedstawiają. Można także zwątpić w ich naturalność i niepodważalność, można dostrzec ich konwencjonalność i prowizoryczność. Takie odwieszenie wątpliwości w odniesieniu do własnej wiedzy nie zawsze nam odpowiada. W każdym razie nie odpowiada nam ono tak długo, jak długo nie potrafimy dostrzec wartości, którym mogłoby ono służyć" [Kwaśnica 2007: 29].

Robert Kwaśnica odpowiedzialność za wybór drogi, którą podąża nauczyciel-pedagog, w swym życiu zawodowym, składa na ręce samego nauczyciela. To od jego zaangażowania, otwartości jego umysłu oraz woli i umiejętności niestandardowego działania zależy bowiem, czy w swej pracy pójdzie z nurtem wyznaczanym przez racjonalność adaptacyjną, próbując ucznia z deficytem wtłoczyć $\mathrm{w}$ dobrze znane ramy edukacji skonstruowane z myślą o uczniach pełnosprawnych, czy też podejmie trud i wyzwanie jakie stanowi racjonalność emancypacyjna, by umożliwić urzeczywistnienie się idei procesu inkluzji [Moszyńska 2016: 222]. Tempo naturalnej ewolucji sposobu myślenia i pracy nauczycieli nie nadąża za wprowadzonymi rozwiązaniami prawnymi, powodując dysonans, którego "ofiarą" staje się proces edukacji włączającej. Wydawać by się mogło, że "dobre praktyki zawodowe" i przypisywane do zawodu nauczyciela "powołanie", powinny skutkować u nauczyciela wewnętrzną potrzebą dostosowywania posiadanego poziomu wiedzy i umiejętności do wyzwań, jakie stawiają przed nimi nowe sytuacje i problemy oświatowe w aspekcie integracji. Ten sposób myślenia o swojej pracy wydaje się być kodem dostępu do adekwatnego w czasie dostosowania się do zmieniającej się rzeczywistości edukacyjnej w zakresie współczesnego ucznia. Proces inkluzji należy zatem oprzeć o całokształt działań prawnych, informacyjnych, szkoleniowych, prewencyjnych. Przemyślane oraz zaplanowane w czasie działanie zagwarantuje powodzenie projektu inkluzji w polskiej szkole.

\section{Bibliografia}

Babbie E. (2003), Badania społeczne w praktyce, Wydawnictwo Naukowe PWN, Warszawa.

Bakoń K., Siedlecka K. (2005), Ocena ucznia przezwlekle chorego w szkole [w:] Uczeń z chorobq przewlekła i uczeń z zaburzeniami psychicznymi w szkole ogólnodostępnej, T. Kott (red.), MENiS, Warszawa.

Brzezińska A.I., Ohme M., Resler-Maj A., Kaczan R., Wiliński M. (2009), Droga do samodzielności. Jak wspomagać rozwój dzieci i młodzieży z ograniczeniami sprawności, GWP, Gdańsk. 
Chęcińska M. (2005), Realizacja obowiązku szkolnego przez dziecko przewlekle chore [w:] Uczeń z choroba przewlekła i uczeń z zaburzeniami psychicznymi w szkole ogólnodostępnej, T. Kott (red.), MENiS, Warszawa.

Gołubiew-Konieczna M. (2011), Dzieci i młodzież przewlekle chora w systemie polskiej oświatypróba oceny [w:] Dziecko przewlekle chore - problemy medyczne, psychologiczne i pedagogiczne, B. Antoszewska (red.), Wydawnictwo Edukacyjne Akapit, Torun.

Z. Gajdzika (2013), Inkluzja wymaga wsparcia: edukację włączająca trzeba rozwijać, ale szkoty specjalne też sa potrzebne, rozmowa przeprowadziła H. Drachal, „Głos Nauczycielski” 2013, nr 20.

Kwaśnica R. (2007), Dwie racjonalności, Wydawnictwo Naukowe Dolnośląskiej Szkoły Wyższej Edukacji TWP, Wrocław.

Moszyńska M. (2016), Środowisko szkolne w narracjach uczniów z Zespołem Aspergera, nieopublikowana rozprawa doktorska pod kierunkiem prof. Amadeusza Krause, Gdańsk.

Rubacha K. (2003), Paradygmaty nauk społecznych a budowanie teorii pedagogicznych [w:] Pedagogika. Podręcznik akademicki, Z. Kwieciński, B. Śliwerski (red.), t. 1, PWN, Warszawa.

Sadowska S. (2016), Kształcenie integracyjne dzieci z niepetnosprawnościa intelektualna - krytyczny bilans pierwszych strukturalnych zmian w systemie edukacji, „Przegląd Badań Edukacyjnych Educational Studies Review", nr 23.

System Informacji Oświatowej - dostęp: Wydział Edukacji - Urząd Miasta Olsztyn - przygotował: Leszek Piskorski.

Szatur-Jaworska B. (2005), Uwagi o ekskluzji i inkluzji na przykładzie polityki spotecznej wobec ludzi starych [w:] Ekskluzja i inkluzja społeczna. Diagnoza - uwarunkowania - kierunki działań, J. Grotowska-Leder, K. Faliszek (red.), Wydawnictwo Edukacyjne Akapit, Torun.

Żelazo M. (2013), Kwestionariusz wywiadu jako narze?dzie badawcze, Obronnosěcě, ,ZZeszyty Naukowe Wydziału Zarza?dzania i Dowodzenia Akademii Obrony Narodowej", nr 2(6). 